This paper reports the improved model design of an auger thermo-radiation dryer for drying plant-derived pomace under a low-temperature mode $\left(35 . .880^{\circ} \mathrm{C}\right)$ to the resulting moisture content at the level of $8 . . .13 \%$ of solids. The dryer has an adjustable speed of auger rotation (3...4 $\left.\mathrm{min}^{-1}\right)$, of airflow $(0.05 \ldots 0.09 \mathrm{~m} / \mathrm{s})$, and is characterized by the uniform distribution of heat flux. It is equipped with an energy-saving two-circuit complex that utilizes secondary energy to heat primary air from $21.1^{\circ} \mathrm{C}$ to $28.9^{\circ} \mathrm{C}$. The use of Peltier elements, installed at the heating technical surface of the dryer's auger, makes it possible to convert thermal energy into a low-voltage supply voltage for the autonomous supercharger and exhaust fans.

The duration of pomace drying in the model structure of the auger thermo-radiation dryer has been determined, in particular tomato pomace, with an initial content of $75 \%$ of solids, which is 107 min. For apple pomace whose starting content of solids is $65 \%$, it is 98 min. For comparison, the duration of the convective drying of tomato pomace (75\% of solids) is 120 minutes. The drying was carried out at a temperature of $60^{\circ} \mathrm{C}$ to the resulting moisture content of $10 . . .12 \%$ of solids. Organoleptic evaluation on the example of tomato pomace confirms the effectiveness of structural solutions in the auger dryer compared to the convective technique.

The results reported in this study could create conditions for the further design and implementation of the proposed structure of thermo-radiation dryer for drying plant-derived pomace involving an altered heat supply technique and the utilization of secondary energy. The designed structure of the device makes it possible to process and preserve the quality properties of plant-derived pomace, allowing the use of this product for a wide range of foodstuffs

Keywords: auger thermo-radiation dryer, plant-derived pomace, drying kinetics, temperature field

\title{
DESIGN OF AN AUGER THERMO- RADIATION DRYER FOR DRYING PLANT-DERIVED POMACE
}

\author{
Tetiana Herasymenko \\ $\mathrm{PhD}$, Assistant \\ Department of Automation and \\ Computer Technologies of Control Systems \\ National University of Food Technologies \\ Volodymyrska str., 68, Kyiv, Ukraine, 01601 \\ E-mail: herasymenko.ta86@gmail.com \\ Katerina Silchenko \\ Senior Lecturer \\ Department of Animal Husbandry and Food Technologies \\ Luhansk National Agrarian University \\ Slobozhanska str., 68, Starobilsk, Ukraine, 92703 \\ Anna Hotvianska \\ $\mathrm{PhD}^{*}$ \\ Galyna Kyrsanova \\ PhD, Associate Professor* \\ Nina Budnyk \\ $\mathrm{PhD}$, Associate Professor** \\ Alla Kainash \\ $\mathrm{PhD}$, Associate Professor** \\ Lyudmila Polozhyshikova \\ $\mathrm{PhD}$, Associate Professor \\ Department of Food Industry Technologies and Restaurant Industry \\ Poltava University of Economics and Trade \\ Koval str., 3, Poltava, Ukraine, 36014 \\ Iryna Taraymovich \\ $\mathrm{PhD}$, Associate Professor \\ Department of Technologies and Equipment of Processing Industries \\ Lutsk National Technical University \\ Lvivska str., 75, Lutsk, Ukraine, 43018 \\ *Department of Plant Production \\ Dnipro State Agrarian and Economic University \\ Serhiya Yefremova str., 25, Dnipro, Ukraine, 49600 \\ **Department of Food Production \\ Poltava State Agrarian Academy \\ Skovorody str., 1/3, Poltava, Ukraine, 36003
}

Received date 08.04.2021 Accepted date 18.05.2021 Published date 10.06.2021
How to Cite: Herasymenko, T., Silchenko, K., Hotvianska, A., Kyrsanova, G., Budnyk, N., Kainash, A., Polozhyshnikova, L., Taraymovich, I. (2021). Design of an auger thermo-radiation dryer for drying plant-derived pomace. Eastern-European Journal of Enterprise Technologies, 3 (1 (111)), 62-69. doi: https://doi.org/10.15587/1729-4061.2021.232116

\section{Introduction}

Plant raw materials are a natural source of various physicochemical elements while processing them involves the production of secondary raw materials. A large proportion of secondary raw materials (peels, pits, etc.) with a variety of substances such as vitamins, trace elements, whose content of solids is $5 \ldots .45 \%$, is reduced by the duration of raw material processing, storage, and further sales in general. Processing the pomace could bring down the level of waste and would make it possible to obtain semi-finished products of varying degrees of readiness, followed by their use in the 
form of natural functional-physiological fillers for many food products [1]. Minimizing the secondary natural raw materials while implementing innovative structural-technological solutions could ensure the preservation of natural sources from the moment of harvesting to making various health products for daily consumption [2]. Obtaining high-quality dried pomace of plant origin during drying would reduce the volume of raw materials, transportation and storage costs, and create high recovery capacity. Dried plant-derived pomace could be used as finished and pre-blended products for various functional and physiological purposes to form healthy diets, including fast foodstuffs, etc.

A relevant task for the processing industry is the development and implementation of innovative ways to design fundamentally new and improve existing heat and mass exchange equipment while applying modern engineering and technological solutions. That specifically includes designing an auger thermo-radiation dryer for drying plant-derived pomace to the required solids content for further technological solutions. Intensifying and implementing high-quality heat and mass exchange process while using modern automation tools, low-inertial infrared heaters, energy-saving complexes for the conversion of secondary energy, etc., would, in turn, ensure the competitiveness of the hardware and technological process. That creates conditions for obtaining high-quality dried semi-finished products of the high degree of readiness in the form of plant-derived pomace to introduce it into food and pharmaceutical technologies to produce multifunctional health foodstuffs.

\section{Literature review and problem statement}

Paper [3] gives recommendations from such global organizations as the World Health Organization (WHO), Food and Agriculture Organization (FAO), and others on the need to consume fruits and vegetables. That could greatly minimize the risk of chronic diseases and provide the necessary support for the body with the necessary natural elements in the context of pandemics. In addition, the daily diet based on plant raw materials, including organic, requires the processing and food industry to find innovative ways to implement this process, which is due to the following [4]:

- the use of technical equipment that has certain structural-technological shortcomings, including high energy and metal consumption, the lack of energy-saving complexes, a significant percentage of processing waste, etc.;

- the development of pandemics and the alarming state of the environment, requiring the introduction of high-quality diets to increase the immunity of the population, including people under extreme conditions, specifically doctors and military personnel [5].

Study [6] analyzed the level of waste from fresh vegetables and fruits in the EU countries from harvesting to the moment of an offer to the consumer; it was established that almost $30 \%$ of waste is generated during processing. Several types of waste have been defined during the research, in particular, the presence of household waste associated with the use of fresh plant raw materials approaches zero, as opposed to the share of waste during processing, which must be decreased. The level of waste in countries is associated in most cases with the development of the processing sector and the quality of resource-efficient processing, including plant-derived pomace as a natural source of the functional-physiological ingredients.
At the same time, the difficult ecological situation and the spread of pandemics require maximum resource efficiency from the processing sector and, from the food industry, the production of high-quality health food of natural origin [7, 8]. However, the issues of ensuring innovative ways to achieve resource-efficient processing of plant raw materials in connection with a certain level of development of the processing sector remain unresolved, which emphasizes the expediency of introducing modern structural-technological solutions. One of the options for overcoming the related difficulties in many countries is the introduction of state programs for the development of the processing and food sectors. That could minimize the level of waste, in particular plant-derived pomace, and produce natural semi-finished products for the manufacture of functional and healthy foodstuffs. In work [9], attention is paid to the rational processing of plant raw materials already in the first stages of processing with the use of innovative equipment to achieve resource-efficient manufacturing processes with maximum preservation of the initial properties of raw materials. That would make it possible to produce high-quality natural ingredients for the further manufacturing of «natural food», which is the subject of several recent studies by many world scientists and is a key trend in the food industry $[10,11]$.

Paper [12] summarizes the state of the food industry in Ukraine, which could be used to form ways of modernization of processing complexes to further ensure resource-efficient processing of plant raw materials. However, there are unresolved issues related to a decrease in the level of waste in the processing of plant raw materials during the basic heat and mass exchange operations, in particular, concentrating and drying. This is due to that most innovative solutions implemented industrially are aimed primarily at the modernization and development of fundamentally new heat and mass exchange equipment. Specifically, works [13-16] report ways to constructively and technologically improve rotary evaporators based on modern engineering solutions while determining only the impact of the thickness of the processed raw materials. Papers $[15,17,18]$ address the effectiveness of the proposed structural solutions during the modernization of evaporators with a variety of heat supply techniques. However, the issue of processing extracted plant-derived pomace after rubbing (peels, pits, etc.) that contain a significant number of useful natural elements is not considered. That emphasizes the expediency of research aimed at minimizing the level of waste at processing enterprises through the introduction of innovative solutions and the development of appropriate technological equipment.

Works [19-21] describe methods for processing secondary raw materials (waste) by extraction and sonication with the possibility of further use, in particular in the food industry. However, there are unresolved issues related to the complete processing of pomace. This is due to that these procedures leave a certain amount of waste that needs further processing or disposal. One of the ways to eliminate these shortcomings is the use of technologies for drying plant-derived pomace, which could create full-fledged processing under rational modes for maximum preservation of natural properties. Paper [22] notes the expediency of using energy-efficient dryers for gentle heat treatment of plant raw materials based on the use of modern flexible film resistive electric heater of emitting type (FFREhEt) [23]. Work [24] notes the growing energy crisis, which needs the introduction of alternative green energy; however, there is 
a technological gap in this area, predetermining the development of energy-efficient dryers, which is a complex structural and technological task. Paper [25] defines the effectiveness of the use of infrared drying of grape pomace film using a surface temperature of 40,45 , and $50{ }^{\circ} \mathrm{C}$, under natural and forced convection. However, questions remain about the formation of a film layer of raw materials and the impact of consistency. It was found that, unlike forced convection, it is better to use the values of airflows close to the parameters of free convection. Work [26] describes a radiation single-drum dryer for drying plant concentrates in the form of a film layer on a corrugated surface; it could be adapted for the rational processing of pomace by upgrading the smearing device. Study [27] notes the effectiveness of the use of certain ranges of infrared waves during the heat and mass exchange processing of peach pomace compared to the treatment with hot air. Paper [29] considers the impact of air drying of apple pomace and the received polyphenol capacity; however, there is a difficulty in using this technology in most countries. One of the ways to resolve it is the attempt to construct comprehensive technological equipment for the simultaneous processing of plant raw materials and the pomace obtained. For example, the process of concentrating might be combined with the possibility of further drying of concentrates and extraction in dryers with a film application of the dried raw materials [29].

Paper [30] notes that most secondary raw materials in the form of agricultural waste from the agro-industrial complex and food industry could be used in the form of gel-forming pectin substances with a purity criterion established by FAO and EU. Works [30,31] indicate the possibility of using dried fractions of plant-derived pomace for the manufacture of biocomposites for food packaging. The expediency of using the dried fractions of olive pomace, which are rich in various macro-and microelements and could be used as fillers in thermoplastic matrices, has been established. The use of manufactured olive fractions reduces the breaking strength of the biocomposites used; in that case, the Young modulus is not significantly affected. However, the level of automation of the technological process of production of containers remains undetermined, since it is in compliance with the technology that the further quality of storage of packed products depends until the consumption [32]. The existing dryer structures have in most cases certain structural and technological shortcomings due not only to production needs but also to low resource efficiency, the lack of energy-saving complexes, and the use of high-temperature heat sources, etc. [33, 34]. In addition, unresolved are the issues related to designing fundamentally new equipment or improving available machinery for high-quality processing of plant-derived pomace. At the same time, it is necessary to use modern heating elements, to introduce resource-efficient complexes that utilize secondary energy, which, in general, would ensure the quality of the technological process at all stages of the heat treatment of plant raw materials. One of the ways of resource efficiency is the conversion of secondary energy for various technological needs (for heating, the autonomy of certain nodes, obtaining power voltage, etc.) by using Peltier elements. Works [35, 36] describe the advantages of using Peltier elements and their effectiveness, at the small size of their contact surfaces, to form, in particular, low-volt power voltage. Consequently, this approach allows them to be used in heat and mass exchange devices for the conversion of secondary energy in accordance with engineering and technological needs, predetermining the expediency of research into this area.
Ensuring the full processing of plant raw materials not only into one component (sugar, juice, etc.) but also semi-finished products of different levels of readiness (an extract, molasses, a concentrate, dried fractions, etc.) could make it possible to obtain natural high-quality components. The introduction of secondary plant raw materials in the formulation composition of food products would make it possible not only to expand the range of food products but also to artificially increase the usefulness of consumption. That could replace the content of various artificial dyes, flavors, etc., received without the use of natural plant-derived components, which would increase the nutritional value of products; it is relevant in a pandemic. Paper [37] notes the effectiveness of the use of waste from processing fruits and vegetables into natural extracts with high antioxidant properties with the possibility of using them in various food and pharmaceutical technologies.

Works [38-41] report studies on determining the effectiveness of adding various natural fillers, in particular grape pomace, as well as pasty concentrates, etc. on the functional and physiological properties and nutritional value of bakery and confectionery products. This emphasizes the prospects of processing plant-derived pomace into semi-finished products with a varying degree of readiness to ensure and form the health rations of the entire population.

The above confirms the expediency of conducting scientific and practical research aimed at designing the heat and mass exchange equipment for drying plant-derived pomace. The resulting pomace could be used in the food and pharmaceutical industry to produce functional food products with therapeutic and prophylactic properties on a natural basis. The main disadvantage of the heat and mass transfer drying process is the energy and metal consumption of the equipment due to the use of a high-temperature steam heat carrier. One should note the minimum level of use of energy-saving complexes associated with the complexity of resource-efficient conversion of secondary energy for technological needs in a single complex of equipment. All this greatly affects the indicator of resource efficiency of processing enterprises in general, although it has in most cases structural and technological shortcomings, which also affect the resulting quality of the products received. The introduction of the above factors during the production of high-quality dried pomace of plant origin could ensure the production of modern heat and mass exchange equipment with competitive properties. Therefore, it is advisable to design an auger thermo-radiation dryer for drying plant-derived pomace at the intensified thermoradiation heat supply. In this case, a proposed heater to be used in the apparatus is a modern flexible film resistive electric heater of emitting type (FFREhEt) [23], which could ensure a stabilized temperature mode and resource efficiency.

\section{The aim and objectives of the study}

The purpose of this work is to design an auger thermoradiation dryer for drying plant-derived pomace at the intensified thermo-radiation heat supply. That could make it possible to introduce a waste-free, resource-efficient, and low-temperature processing of plant-derived pomace while using innovative structural-technological solutions.

To accomplish the aim, the following tasks have been set:

- to design a model structure of a thermo-radiation dryer for drying plant-derived pomace with a modified technique of heat supply and the use of secondary energy; 
- to investigate the uniformity of a temperature field in the designed dryer, the kinetics of the moisture content during the thermo-radiation drying of plant-derived pomace, and to perform a comparative organoleptic assessment of dried tomato pomace.

\section{The study materials and methods}

This study was carried out at the Research Center «Newest Biotechnology and Equipment for the Production of Foodstuffs with High Wellness Properties», Kharkiv State University of Nutrition and Trade (Ukraine).

We examined and tested the drying of tomato and apple pomace in the designed model structure of a thermo-radiation dryer with real-time determining of the uniformity of the temperature field and the kinetics of the process.

The moisture content of the examined samples was determined using generally accepted procedures. The weight of wet and dried materials was determined by laboratory scales, the time of the experiment $(\tau)$ was registered by a stopwatch and characterized the duration of raw material passage through a drum, followed by entering the container with the dried material. The initial and resulting moisture content of raw materials was determined by drying them in pre-prepared cuvettes by bringing them to a constant mass. The moisture content kinetics were calculated experimentally when weighing the examined samples in the drying process before loading, over a certain period, and after unloading. The statistical reliability of the experimental studies was provided by five-time repeatability when treating the data acquired at the level of 0.95 according to Fisher-Student. The margin of error from the experimental set-up is 0.03 .

The organoleptic properties were assessed by an expert board consisting of 5 members from the Research Center, based on organoleptic properties (appearance, color, smell, taste, and consistency).

\section{Determining the effectiveness of solutions in the improvement of an auger thermo-radiation dryer}

\section{1. Design of the improved model of an auger thermo- radiation dryer \\ The first step in determining the effectiveness of the adop-} ted structural and technological solutions was the improvement of the model structure of an auger thermo-radiation dryer for drying plant-derived pomace (Fig. 1). The operation of the device is as follows: the pomace enters loading hopper 1 with string dividers 2 for preliminary separation of the volume of experimental raw materials before entering working chamber 3 of the auger thermo-radiation dryer. The body of the auger thermo-radiation dryer is a stainless cylindrical working surface, from the outer surface of which there is a flexible film resistive electric heater of radiating type (FFREhEt) 4. A peculiarity of the working organ (auger 5) of the thermo-radiation auger dryer is the ability to heat its inner surface with heater 4 . To prevent the sticking of the examined samples, from the first to the third turns of auger 5 there are additionally placed blade dividers 6, which is explained by the higher initial moisture content and, therefore, the ability to stick, which leads to uneven drying.
Fig. 1. The improved model of an auger thermo-radiation dryer

rying plant-derived pomace: 1 - loading hopper; 2 - string dividers;

- working chamber; 4 - flexible film resistive electric heater

the use of spent secondary air (two-ring channel); 8 - injection fan;

9 - the internal space of the two-ring channel; 10 - exhaust fan;

11 - the outer space of the two-ring channel; 12 - thermal insulating

uviation; 13 - Peltier elements; 14 - secondary air drainage nozzle; y air nozzle; 16 - unloading hopper; 17 - racks; 18 - control unit of technological parameters; 19 - reducer

The model built is provided with a unit for the use of spent secondary air 7 (a two-ring channel) for heating and partial drying of primary air, ensuring the intensification of moisture absorption during the passage of the working chamber of dryer 3. Fan 8 pumps the primary air first to internal space 9 of the two-ring channel through nozzle 15, followed by entering working chamber 3. Exhaust secondary air $\left(35 \ldots 80^{\circ} \mathrm{C}\right)$, with the help of exhaust fan 10 , enters outer space 9 of the two-ring channel and is discharged into the environment through nozzle 14 . Thus, the two-ring complex ensures the intensification of heat exchange between airflows, and the additional coating of the dryer body with thermal insulating alluvium 12 ensures the reduction of losses to the environment. The auger thermo-radiation dryer has modern means of converting secondary thermal energy into a low-voltage power supply by Peltier elements 13 arranged at the technical cylindrical outer surface of the heated auger 5 .

Experimental raw materials, after entering the working chamber of auger dryer 3 , moves to unloading hopper 16 , undergoing the drying process $\left(35 \ldots 80^{\circ} \mathrm{C}\right)$ to the resulting moisture content at the level of $8 . . .13 \%$ of solids. The dryer is placed on racks 17 , the auger rotation is enabled by a reducer with an adjustable speed 19; there is a control unit for technological parameters 18 (temperature, the auger speed, etc.).

5. 2. Determining the temperature field uniformity in the designed dryer and the kinetics of the drying process

The second stage during the approbation of the designed model structure of an auger thermo-radiation dryer for drying plant-derived pomace was to determine the uniform distribution of the temperature field in a working chamber (without loading raw materials). To determine the temperature field, we randomly placed inside the working chamber of the auger thermo-radiation dryer 10 chromel-copel thermocouples connected to the «TPM-136» connected to a personal computer. The layout of thermocouples and the window with the output data for each thermocouple within the working space of the auger thermo-radiation dryer are shown in Fig. 2.

Analyzing the real-time data on the temperature field, one can conclude that the temperature field is uniform (data from the indications of thermocouples No. 3-6 and 9-10 with an average value of $60^{\circ} \mathrm{C}$ ). And, therefore, the uniformity of heating the working space is ensured, including when drying plant-derived pomace in the proposed model structure. Minor deviations in temperature values could be considered 
within the experimental error. Thermocouple 2 is installed at the input of the exhaust fan and, by placing thermocouples 2-1 and 2-2 in the outer space of the two-ring channel, makes it possible to measure the cooling level of the secondary air. In this case, thermocouple 8 is mounted on the supercharger fan, thermocouples 8-1 and 8-2 make it possible to measure a change in the medium temperature in the internal space of the two-ring channel before entering the working chamber. Primary air passes between the FFREhEt heating surface and the outer pipe of the two-ring channel with insulating alluvial, thereby inducing a conductive heating technique, allowing for an increase in the air temperature from $21.1^{\circ} \mathrm{C}$ to $28.9{ }^{\circ} \mathrm{C}$. After confirming the uniformity of thermal energy in the model structure of the auger thermoradiation dryer, we determined the kinetics of moisture content in the examined samples of tomato and apple pomace with a mass fraction of moisture of $75 \% \mathrm{SM}$ and $65 \% \mathrm{SM}$, respectively. The examined samples were dried in the model structure of the auger thermo-radiation dryer at a temperature of $60{ }^{\circ} \mathrm{C}$, the speed of auger rotation was $3 . . .4 \mathrm{~min}^{-1}$; that of the airflow $-0.05 \ldots 0.09 \mathrm{~m} / \mathrm{s}$ to the resulting moisture content of $10 . .12 \%$ SM (Fig. 3).

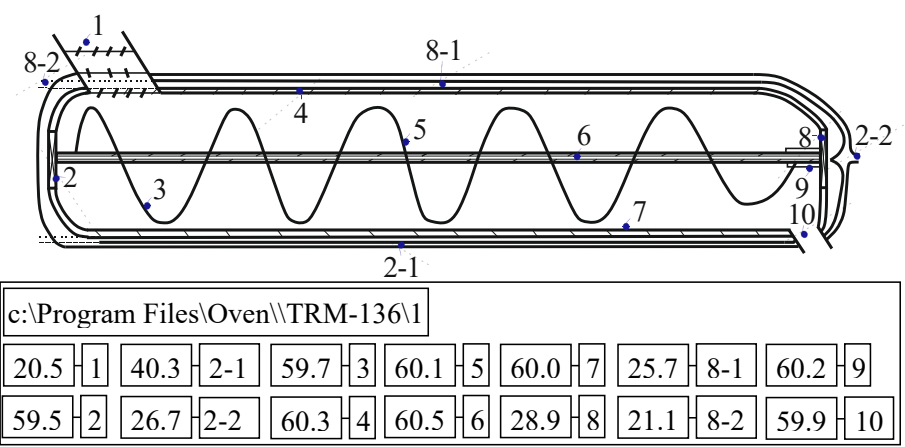

Fig. 2. The layout of thermocouples location and the visualization of temperature data within the working space of the auger thermo-radiation dryer

Analyzing the kinetics of moisture content of pomace in the model structure of the auger thermo-radiation dryer, it was determined that the duration of drying tomato pomace whose initial content of solids is $75 \%$ is 107 minutes. For apple pomace whose starting content of solids is $65 \%$, it is 98 minutes; for comparison, the kinetics of drying is given at the convective drying of tomato pomace ( $75 \%$ of solids) with a process duration of 120 minutes. The obtained data confirm the expediency of using the proposed model structure of the auger thermo-radiation dryer for drying plant-derived pomace.

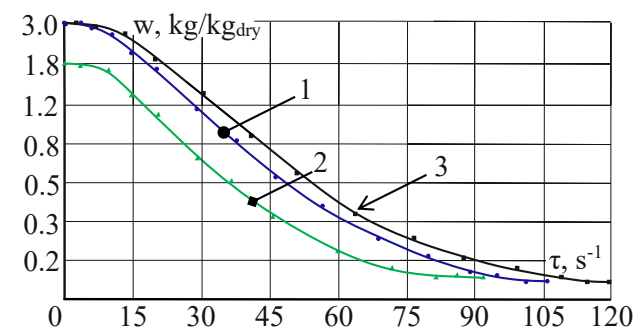

Fig. 3. The kinetics of moisture content:

1 - tomato pomace and apple pomace; 2 - pomace in the model structure of the auger thermo-radiation dryer; $3-$ tomato pomace at convective drying
We have performed the comparative organoleptic assessment of the dried tomato pomace obtained in the model structure of the auger thermo-radiation dryer and at convective drying (Table 1 ).

Table 1

\section{Comparative organoleptic assessment} of dried tomato pomace

\begin{tabular}{|c|c|c|}
\hline \multirow{2}{*}{ Indicator } & \multicolumn{2}{|c|}{ Characteristic } \\
\cline { 2 - 3 } & $\begin{array}{c}\text { thermo-radiation } \\
\text { technique }\end{array}$ & $\begin{array}{c}\text { convective } \\
\text { technique }\end{array}$ \\
\hline Appearance & Homogeneous finely-dispersed fractional mass \\
\hline Taste and smell & $\begin{array}{c}\text { Pleasant harmonious taste } \\
\text { and smell of tomatoes }\end{array}$ & $\begin{array}{c}\text { Taste and smell } \\
\text { of tomatoes }\end{array}$ \\
\hline Color & Red-orange, pronounced & Dark-orange \\
\hline
\end{tabular}

The established organoleptic indicators of the tomato pomace obtained in the model structure of the auger thermo-radiation dryer have the pronounced taste and smell inherent in fresh tomatoes without a taste of burning, in contrast to convective drying. Dried tomato pomace after the auger dryer has a bright red-orange coloration; after the convective technique - dark orange, which is explained by a higher processing temperature, uneven heat flow, and drying mainly surface layers. The organoleptic evaluation testifies to the effectiveness of the proposed structural solutions, which makes it possible to get samples with higher organoleptic properties.

\section{Discussion of results of drying plant-derived pomace in the auger thermo- radiation dryer}

The auger thermo-radiation dryer for drying plant-derived pomace, due to the proposed structural-technological solutions, is characterized by a low-temperature combined technique of heat supply in the range from $35^{\circ} \mathrm{C}$ to $80^{\circ} \mathrm{C}$. It has an adjustable variable speed of auger rotation of $\left(3 \ldots .4 \mathrm{~min}^{-1}\right)$ and airflow $(0.05 \ldots 0.09 \mathrm{~m} / \mathrm{s})$ and makes it possible to dry raw materials to the resulting moisture content of $8 . .13 \%$ of solids. The dryer is characterized by the uniform distribution of heat flow, which is confirmed by thermocouple data (Nos. 3-6 and 9-10 with an average value of $60^{\circ} \mathrm{C}$, Fig. 2). The device is equipped with an energy-saving unit for the use of secondary energy for heating air from $21.1^{\circ} \mathrm{C}$ to $28.9{ }^{\circ} \mathrm{C}$ (the data acquired in real time from thermocouples 8, 8-1, and 8.2, Fig. 2). The use of Peltier elements 13, located at the heating technical surface of auger 5 (Fig. 1), makes it possible to convert thermal energy into a low-voltage power supply for autonomous supercharger 8 and exhaust 10 fans. The duration of drying tomato pomace with a starting content of solids of $75 \%$ is 107 min., apple pomace ( $65 \%$ of solids), is $98 \mathrm{~min}$., while the duration of the comparative convective drying of tomato pomace is $120 \mathrm{~min}$. That confirms the possibility of using the proposed auger thermo-radiation dryer for the high-quality drying of plant-derived pomace, with the subsequent use in the food and pharmaceutical industries. 
A special feature in using the auger thermo-radiation dryer for drying pomace of plant origin is to ensure the effective processing of plant raw materials, including pomace. It contains, after many technological operations, a significant number of functional and physiological ingredients, which, at high-quality processing, could be applied in many areas of nutrition. At the same time, the introduction of pomace processing equipment would further increase the level of these enterprises in the international arena, and, therefore, competitiveness in the high-quality technological process. Most auger dryers and machines for pomace drying are characterized by metal and energy consumption because of the use, in most cases, of the high-temperature steam heat supply systems, accompanied by losses of useful functional and physiological ingredients of plant origin [42].

The limitation in the approbation of the designed auger thermo-radiation dryer was the use of two varieties of pomace (tomato and apple) while others would have a similar structure and differ in the initial moisture content. The disadvantage of this study is a certain difficulty in selecting the rational modes of auger rotation and airflow, to maximize the efficiency of the process, predetermining the need for an adaptive drying process for each raw material. This approach would make it possible to build a generalized database on the rational modes of thermo-radiation drying of plant-derived pomace.

Further research will be aimed at compiling a generalized base on the thermo-radiation drying of plant-derived pomace in the auger dryer. And a further comparison of the proposed structural-technological solutions, previously confirmed by the scientific and practical research on their effectiveness, when comparing the results obtained with the industrial analogs of dryers. A certain difficulty in comparing them will be the difference between low-temperature and high-temperature heat and mass exchange treatment when using different heat carriers and design features. To simplify engineering and technological tasks, we plan in the future to employ software for the simulation and preliminary analysis of the effective and rational heat and mass transfer process with subsequent technical design.

\section{Conclusions}

1. We have improved a model design of the auger thermo-radiation dryer for drying plant-derived pomace under a low-temperature mode $\left(35 \ldots 80^{\circ} \mathrm{C}\right)$ to the resulting moisture content at the level of $8 . . .13 \%$ of solids. The dryer has a variable speed of rotation of the auger $\left(3 \ldots .4 \mathrm{~min}^{-1}\right)$ and airflow $(0.05 \ldots 0.09 \mathrm{~m} / \mathrm{s})$ and is characterized by the uniform distribution of heat flow (the data from thermocouples No.3-6 and 9-10 with an average value of $60^{\circ} \mathrm{C}$ ). The device is equipped with an energy-saving two-ring unit for the use of secondary energy to heat the primary air from $21.1^{\circ} \mathrm{C}$ to $28.9^{\circ} \mathrm{C}$ (the data from thermocouples $8,8-1$, and 8-2). The use of Peltier elements 13, located at the heating technical surface of auger 3 makes it possible to convert thermal energy into a low-voltage power supply to autonomous supercharger 8 and exhaust 10 fans.

2. The uniformity of the temperature field in the working chamber of the dryer has been confirmed (thermocouples No. 3-6 and 9-10 with an average value of $60^{\circ} \mathrm{C}$ ). The data from thermocouple 8 , placed at the input of the pumping fan and additional thermocouples 8-1 and 8-2 (in the internal space of the two-ring channel) indicate heating the fresh air by $7.5^{\circ} \mathrm{C}$ by a conductive technique. We have determined the duration of pomace drying in the model structure of the auger thermo-radiation dryer; in particular, for tomato pomace with an initial content of $75 \%$ of solids, 107 minutes. For apple pomace with a starting content of solids of $65 \%-$ $98 \mathrm{~min}$. For comparison, the duration of convective drying, when using an example of tomato pomace ( $75 \%$ of solids), is 120 minutes. The drying was carried out at a temperature of $60{ }^{\circ} \mathrm{C}$ to the resulting moisture content of $10 \ldots 12 \%$ of solids. The effectiveness of the proposed structural solutions has been confirmed by the results of organoleptic evaluation on the example of tomato pomace in comparison with the convective technique.

\section{Acknowledgment}

We express our gratitude to the Research Center «Newest Biotechnology and Equipment for the Production of Foodstuffs with High Health Properties» at Kharkiv State University of Nutrition and Trade (Ukraine) represented by Mr. Oleksiy Zagorulko and Mr. Andriy Zagorulko who helped in the implementation and approbation of the designed model structure of the auger thermo-radiation dryer for drying plant-derived pomace. This work was funded by the state budget, theme No. 1-21 BO «Development of technological processes and low-temperature equipment for the production of multifunctional semi-finished products and confectionery products using organic raw materials» under the guidance of Associate Professor Andriy Zagorulko.

1. Niemira, B. A., Fan, X. (2014). FRUITS AND VEGETABLES | Advances in Processing Technologies to Preserve and Enhance the Safety of Fresh and Fresh-Cut Fruits and Vegetables. Encyclopedia of Food Microbiology, 983-991. doi: https://doi.org/10.1016/ b978-0-12-384730-0.00428-6

2. Das, I., Arora, A. (2017). Post-harvest processing technology for cashew apple - A review. Journal of Food Engineering, 194, 87-98. doi: https://doi.org/10.1016/j.jfoodeng.2016.09.011

3. Sucheta, Singla, G., Chaturvedi, K., Sandhu, P. P. (2020). Status and recent trends in fresh-cut fruits and vegetables. Fresh-Cut Fruits and Vegetables, 17-49. doi: https://doi.org/10.1016/b978-0-12-816184-5.00002-1

4. El Sheikha, A. F. (2019). Tracing Fruits and Vegetables from Farm to Fork: Questions of Novelty and Efficiency. Production and Management of Beverages, 179-209. doi: https://doi.org/10.1016/b978-0-12-815260-7.00006-7

5. Vincente, A. R., Manganaris, G. A., Ortiz, C. M., Sozzi, G. O., Crisosto, C. H. (2014). Nutritional Quality of Fruits and Vegetables. Postharvest Handling, 69-122. doi: https://doi.org/10.1016/b978-0-12-408137-6.00005-3

6. De Laurentiis, V., Corrado, S., Sala, S. (2018). Quantifying household waste of fresh fruit and vegetables in the EU. Waste Management, 77, 238-251. doi: https://doi.org/10.1016/j.wasman.2018.04.001 
7. MOZ Ukrainy predstavylo rekomendatsiyi zi zdorovoho kharchuvannia. Available at: https://moz.gov.ua/article/news/ moz-ukraini-predstavilo-rekomendacii-zi-zdorovogo-harchuvannja

8. Román, G. C., Jackson, R. E., Gadhia, R., Román, A. N., Reis, J. (2019). Mediterranean diet: The role of long-chain $\omega-3$ fatty acids in fish; polyphenols in fruits, vegetables, cereals, coffee, tea, cacao and wine; probiotics and vitamins in prevention of stroke, age-related cognitive decline, and Alzheimer disease. Revue Neurologique, 175 (10), 724-741. doi: https://doi.org/10.1016/ j.neurol.2019.08.005

9. Zagorulko, A., Zahorulko, A., Kasabova, K., Chervonyi, V., Omelchenko, O., Sabadash, S. et. al. (2018). Universal multifunctional device for heat and mass exchange processes during organic raw material processing. Eastern-European Journal of Enterprise Technologies, 6 (1 (96)), 47-54. doi: https://doi.org/10.15587/1729-4061.2018.148443

10. Sanchez-Siles, L. M., Michel, F., Román, S., Bernal, M. J., Philipsen, B., Haro, J. F. et. al. (2019). The Food Naturalness Index (FNI): An integrative tool to measure the degree of food naturalness. Trends in Food Science \& Technology, 91, 681-690. doi: https://doi.org/10.1016/j.tifs.2019.07.015

11. Battacchi, D., Verkerk, R., Pellegrini, N., Fogliano, V., Steenbekkers, B. (2020). The state of the art of food ingredients' naturalness evaluation: A review of proposed approaches and their relation with consumer trends. Trends in Food Science \& Technology, 106, 434-444. doi: https://doi.org/10.1016/j.tifs.2020.10.013

12. Pashniuk, L. O. (2012). Food industry of Ukraine: state, tendencies and perspectives of development. Ekonomichnyi ChasopysKhKhI, 9-10, 60-63. Available at: http://dspace.nbuv.gov.ua/bitstream/handle/123456789/48329/18-Pashniuk.pdf?sequence=1

13. Zahorulko, A., Zagorulko, A., Yancheva, M., Ponomarenko, N., Tesliuk, H., Silchenko, E. et. al. (2020). Increasing the efficiency of heat and mass exchange in an improved rotary film evaporator for concentration of fruit-and-berry puree. Eastern-European Journal of Enterprise Technologies, 6 (8 (108)), 32-38. doi: https://doi.org/10.15587/1729-4061.2020.218695

14. Silveira, A. C. P. (2015). Thermodynamic and hydrodynamic characterization of the vacuum evaporation process during concentration of dairy products in a falling film evaporator. Food and Nutrition. Agrocampus Ouest. NNT: 2015NSARB269. Available at: https://tel.archives-ouvertes.fr/tel-01342521/document

15. Cokgezme, O. F., Sabanci, S., Cevik, M., Yildiz, H., Icier, F. (2017). Performance analyses for evaporation of pomegranate juice in ohmic heating assisted vacuum system. Journal of Food Engineering, 207,1-9. doi: https://doi.org/10.1016/j.jfoodeng.2017.03.015

16. Cherevko, O., Mykhaylov, V., Zagorulko, A., Zahorulko, A. (2018). Improvement of a rotor film device for the production of highquality multicomponent natural pastes. Eastern-European Journal of Enterprise Technologies, 2 (11 (92)), 11-17. doi: https:// doi.org/10.15587/1729-4061.2018.126400

17. Ding, Z., Qin, F. G. F., Yuan, J., Huang, S., Jiang, R., Shao, Y. (2019). Concentration of apple juice with an intelligent freeze concentrator. Journal of Food Engineering, 256, 61-72. doi: https://doi.org/10.1016/j.jfoodeng.2019.03.018

18. Zahorulko, A., Zagorulko, A., Fedak, N., Sabadash, S., Kazakov, D., Kolodnenko, V. (2019). Improving a vacuum-evaporator with enlarged heat exchange surface for making fruit and vegetable semi-finished products. Eastern-European Journal of Enterprise Technologies, 6 (11 (102)), 6-13. doi: https://doi.org/10.15587/1729-4061.2019.178764

19. González, M., Barrios, S., Budelli, E., Pérez, N., Lema, P., Heinzen, H. (2020). Ultrasound assisted extraction of bioactive compounds in fresh and freeze-dried Vitis vinifera cv Tannat grape pomace. Food and Bioproducts Processing, 124, 378-386. doi: https:// doi.org/10.1016/j.fbp.2020.09.012

20. Sengar, A. S., Rawson, A., Muthiah, M., Kalakandan, S. K. (2020). Comparison of different ultrasound assisted extraction techniques for pectin from tomato processing waste. Ultrasonics Sonochemistry, 61, 104812. doi: https://doi.org/10.1016/j.ultsonch.2019.104812

21. Asem, M., Jimat, D. N., Jafri, N. H. S., Wan Nawawi, W. M. F., Azmin, N. F. M., Abd Wahab, M. F. (2021). Entangled cellulose nanofibers produced from sugarcane bagasse via alkaline treatment, mild acid hydrolysis assisted with ultrasonication. Journal of King Saud University - Engineering Sciences. doi: https://doi.org/10.1016/j.jksues.2021.03.003

22. Cherevko, A., Kiptelaya, L., Mikhaylov, V., Zagorulko, A., Zagorulko, A. (2015). Development of energy-efficient IR dryer for plant raw materials. Eastern-European Journal of Enterprise Technologies, 4 (8 (76)), 36-41. doi: https://doi.org/10.15587/ 1729-4061.2015.47777

23. Zahorulko, A. M., Zahorulko, O. Ye. (2016). Pat. No. 108041 UA. Hnuchkyi plivkovyi rezystyvnyi elektronahrivach vyprominiuiuchoho typu. No. u201600827; declareted: 02.02.2016; published: 24.06.2016, Bul. No. 12. Available at: http://uapatents. com/5-108041-gnuchkijj-plivkovijj-rezistivnijj-elektronagrivach-viprominyuyuchogo-tipu.html

24. Mohana, Y., Mohanapriya, R., Anukiruthika, T., Yoha, K. S., Moses, J. A., Anandharamakrishnan, C. (2020). Solar dryers for food applications: Concepts, designs, and recent advances. Solar Energy, 208, 321-344. doi: https://doi.org/10.1016/j.solener.2020.07.098

25. Dolgun, E. C., Karaca, G., Aktaş, M. (2020). Performance analysis of infrared film drying of grape pomace using energy and exergy methodology. International Communications in Heat and Mass Transfer, 118, 104827. doi: https://doi.org/10.1016/j.icheatmasstransfer.2020.104827

26. Cherevko, O., Mikhaylov, V., Zahorulko, A., Zagorulko, A., Gordienko, I. (2021). Development of a thermal-radiation single-drum roll dryer for concentrated food stuff. Eastern-European Journal of Enterprise Technologies, 1 (11 (109)), 25-32. doi: https:// doi.org/10.15587/1729-4061.2021.224990

27. Zhou, M., Li, C., Bi, J., Jin, X., Lyu, J., Li, X. (2019). Towards understanding the enhancement of moisture diffusion during intermediate-infrared drying of peach pomace based on the glass transition theory. Innovative Food Science \& Emerging Technologies, 54, 143-151. doi: https://doi.org/10.1016/j.ifset.2019.04.003 
28. Birtic, S., Régis, S., Le Bourvellec, C., Renard, C. M. G. C. (2019). Impact of air-drying on polyphenol extractability from apple pomace. Food Chemistry, 296, 142-149. doi: https://doi.org/10.1016/j.foodchem.2019.05.131

29. Kiptelaya, L., Zagorulko, A., Zagorulko, A. (2015). Improvement of equipment for manufacture of vegetable convenience foods. Eastern-European Journal of Enterprise Technologies, 2 (10 (74)), 4-8. doi: https://doi.org/10.15587/1729-4061.2015.39455

30. Berthet, M.-A., Angellier-Coussy, H., Machado, D., Hilliou, L., Staebler, A., Vicente, A., Gontard, N. (2015). Exploring the potentialities of using lignocellulosic fibres derived from three food by-products as constituents of biocomposites for food packaging. Industrial Crops and Products, 69, 110-122. doi: https://doi.org/10.1016/j.indcrop.2015.01.028

31. Lammi, S., Le Moigne, N., Djenane, D., Gontard, N., Angellier-Coussy, H. (2018). Dry fractionation of olive pomace for the development of food packaging biocomposites. Industrial Crops and Products, 120, 250-261. doi: https://doi.org/10.1016/ j.indcrop.2018.04.052

32. Sashnova, M., Zahorulko, A., Savchenko, T., Gakhovich, S., Parkhomenko, I., Pankov, D. (2020). Improving the quality of the technological process of packaging shape formation based on the information structure of an automated system. Eastern-European Journal of Enterprise Technologies, 3 (2 (105)), 28-36. doi: https://doi.org/10.15587/1729-4061.2020.205226

33. Almena, A., Goode, K. R., Bakalis, S., Fryer, P. J., Lopez-Quiroga, E. (2019). Optimising food dehydration processes: energy-efficient drum-dryer operation. Energy Procedia, 161, 174-181. doi: https://doi.org/10.1016/j.egypro.2019.02.078

34. Promyshlennaya sushka syr'ya dlya APK - obzor tekhnologiy. Available at: https://spark.ru/startup/yavadzhra/blog/16798/ promishlennaya-sushka-siriya-dlya-apk-obzor-tehnologij

35. Liao, M., He, Z., Jiang, C., Fan, X., Li, Y., Qi, F. (2018). A three-dimensional model for thermoelectric generator and the influence of Peltier effect on the performance and heat transfer. Applied Thermal Engineering, 133, 493-500. doi: https://doi.org/10.1016/ j.applthermaleng.2018.01.080

36. Zahorulko, A., Zagorulko, A., Yancheva, M., Serik, M., Sabadash, S., Savchenko-Pererva, M. (2019). Development of the plant for low-temperature treatment of meat products using IR-radiation. Eastern-European Journal of Enterprise Technologies, 1 (11 (97)), 17-22. doi: https://doi.org/10.15587/1729-4061.2019.154950

37. Montenegro-Landívar, M. F., Tapia-Quirós, P., Vecino, X., Reig, M., Valderrama, C., Granados, M. et. al. (2021). Fruit and vegetable processing wastes as natural sources of antioxidant-rich extracts: Evaluation of advanced extraction technologies by surface response methodology. Journal of Environmental Chemical Engineering, 9 (4), 105330. doi: https://doi.org/10.1016/j.jece.2021.105330

38. Nakov, G., Brandolini, A., Hidalgo, A., Ivanova, N., Stamatovska, V., Dimov, I. (2020). Effect of grape pomace powder addition on chemical, nutritional and technological properties of cakes. LWT, 134, 109950. doi: https://doi.org/10.1016/j.lwt.2020.109950

39. Altnok, E., Palabiyik, I., Gunes, R., Toker, O. S., Konar, N., Kurultay, S. (2020). Valorisation of grape by-products as a bulking agent in soft candies: Effect of particle size. LWT, 118, 108776. doi: https://doi.org/10.1016/j.lwt.2019.108776

40. Zahorulko, A., Zagorulko, A., Kasabova, K., Shmatchenko, N. (2020). Improvement of zefir production by addition of the developed blended fruit and vegetable pasteinto its recipe. Eastern-European Journal of Enterprise Technologies, 2 (11 (104)), 39-45. doi: https://doi.org/10.15587/1729-4061.2020.185684

41. Calvete-Torre, I., Muñoz-Almagro, N., Pacheco, M. T., Antón, M. J., Dapena, E., Ruiz, L. et. al. (2021). Apple pomaces derived from mono-varietal Asturian ciders production are potential source of pectins with appealing functional properties. Carbohydrate Polymers, 264, 117980. doi: https://doi.org/10.1016/j.carbpol.2021.117980

42. Canning solutions and food processing equipment. BESTEQ-Engineering. Available at: https://besteq.ru/ 